DOI https://doi.org/10.30525/978-9934-588-80-8-2.26

\title{
«ЕТИКА ЗБРОЙНОЇ БОРОТЬБИ» В СИСТЕМІ КОМПЕТЕНТНОСТЕЙ ОФІЩЕРА В СУЧАСНІЙ УКРАЇНІ
}

\author{
Севрук I. I. \\ кандидат філософських наук, дочент, \\ доиент кафедри соиіально-гуманітарних дисииплін \\ Національна академія Національної гвардї Украӥни \\ Соколовська Ю. В. \\ кандидат історичних наук, доцент, \\ дочент кафедри соиіально-гуманітарних дисииплін \\ Національна академія Національної гвардії України \\ Чупринова Н. Ю. \\ кандидат філологічних наук, доцент, \\ дочент кафедри соиіально-гуманітарних дисииплін \\ Національна академія Національної гвардії Украӥни \\ м. Харків, Україна
}

Збройний конфлікт на Сході України триває більше шести років, породжуючи чисельні соціально-політичні, економічні та моральноетичні проблеми. Очевидною стає залежність успішності ведення бойових дій від ступеня довіри/недовіри суспільства армії, силовим структурам, які задіяні у веденні бойових операцій. Очевидною стає й важливість морально-етичних контекстів ведення бойових дій. Очевидною стає й необхідність надання системних етичних знань військовим.

Орієнтація України на Євроінтеграцію та вступ у НАТО, що була закріплена у Конституції країни у 2019 році [1], потребує формування компетентностей офіцерського корпусу України у відповідності до вимог щодо військових керівних кадрів країн-членів НАТО. Це означає, що у систему підготовки офіцерського складу має бути включеною етична освіта, базовими мають стати морально-етичні цінностей громадянського суспільства та армійська етика.

На думку авторів «Етика збройної боротьби», може розглядатися у декількох вимірах:

- як вимога стандартів щодо компетентностей сучасного офіцерського корпусу; 
- як складова етичної освіти військових та, відповідно, частина спеціалізованої навчальної дисципліни з армійської етики (військовопрофесійної моралі, військово-професійної етики);

- як науково-теоретична проблема, що потребує ретельної науководослідної роботи.

Стандарти вищої освіти, затверджені міністерством освіти України у 2018 році для першого (бакалаврського) рівня для спеціальностей 253 «Військове управління (за видами збройних сил)», 254 «Забезпечення військ (сил)», 255 «Озброєння та військова техніка», містять компетентності та результати навчання, які безпосередньо пов'язані 3 морально-етичною обізнаністю випускників закладів вищої військової освіти України [2; 3; 4].

Так, у всіх названих стандартах зафіксовано, що у якості очікуваних програмних результатів навчання випускник має: «Володіти достатніми знаннями і розумінням сутності та основних питань етики збройної боротьби, визначення універсальних моральних норм в аспекті поведінки учасників збройної боротьби» [2; 3; 4]. Для спеціальностей 253 та 255 це програмний результат 09 (ПР 09), а для спеціальності 254 - програмний результат 02 (ПР 02).

Але формування будь-якої компетентності випускника навчального закладу потребує принаймні наявності навчальних дисциплін, спрямованих на формування даної компетентності та забезпечення програмних результатів навчання. Навчальні плани підготовки офіцерського складу провідних вищих військових закладів сектору безпеки та оборони України демонструють граничну «нейтральність» щодо питань надання майбутнім офіцерам знань щодо етики збройної боротьби, етичного рішення, норм та цінностей, що мають регулювати професійні та соціальні взаємодії тощо.

Так, здебільшого на вивчення проблем етики виділяється від двох до шести годин навчального часу у межах інтегрованих курсів на кшталт «Філософія (Філософія, Релігієзнавство, Логіка, Етика та Естетика)». Лише у двох вищих військових навчальних закладах України Національній академії Національної гвардії України (НА НГУ) (м. Харків) та у Національній академії Державної прикордонної служби імені Богдана Хмельницького (НАДПС) (м. Хмельницький) - і то, лише на одному з факультетів!, - наявні окремі навчальні дисципліни «Військово-професійна мораль» (54 години аудиторної роботи, гуманітарний факультет, НА НГУ) та «Етика професійної діяльності прикордонника» (50 аудиторних годин, факультет Безпеки державного кордону, НАДПС). 
Отже питання щодо етичної освіти майбутніх офіцерів в Україні поки що залишається завданням наскільки перспективним, настільки й складним.

Маємо зазначити, що серед системних викликів, 3 якими зустрічається практична реалізація етичної освіти військових, слід назвати наступні:

- інституціональна інертність системи військового навчання та виховання в Україні, що пояснюється з одного боку, закритістю та консерватизмом військової сфери в цілому, а з іншого, особливостями процесів формування та трансформування національної військової освіти доби незалежності;

- технократичність та консерватизм мислення керівництва ВВНЗ, неготовність до сприйняття ідей обумовлюючої ролі морально-етичної складової у взаємодії армії та суспільства в сучасному світі;

- недостатне усвідомлення військовими керівниками різних рівнів залежності ефективності бойових операцій від етичної обізнаності всіх категорій військовослужбовців;

- нерозуміння військовими в цілому змісту самого поняття «етична освіта», зведення проблем військово-професійної моралі до питань етикету та культури поведінки;

- недостатня обізнаність офіцерського складу щодо тенденцій, які домінують у підготовці військових у країнах-членах НАТО, неврахування морально-етичної та соціальної складових того значного досвіду ведення сучасних бойових операцій, який мають армії цих країн;

- несприйняття ідей етичної освіти старшим поколінням військових через негативний досвід граничної ідеологізації військового навчання та виховання у радянські часи.

Маємо зазначити, що аналіз вітчизняних науково-теоретичних джерел дозволяє стверджувати, що у вітчизняній традиції питання етики збройної боротьби постають майже як певна tabula race. Навіть не відпрацьовано зміст самого поняття «етика збройної боротьби». Здебільшого коло проблем щодо етики збройної боротьби у вітчизняній традиції розгортається у межах нормативо-правового розгляду та зводиться до питань міжнародного гуманітарного права.

Водночас, на переконання авторів, питання етики збройної боротьби формують набагато більш складні контексти виконання бойових завдань. Ці проблеми мають розглядатися також у екзистенційно-життєвому, морально-етичному вимірі, що, до речі дозволить усвідомити і ті складні проблеми соціалізації до мирного життя, з якими зустрічаються учасники сучасних бойових дій у всіх країнах світу. 
Вважаємо, що етика збройної боротьби постає на сьогодні як достатньо перспективний напрям науково-теоретичних досліджень, потребує нагального втілення у межах навчально-виховного процесу у закладах вищої військової освіти України та реалізації у практиках виконання службово-бойових завдань та ведення бойових дій.

\section{Література:}

1. Закон України: Про внесення змін до Конституції України (щодо стратегічного курсу держави на набуття повноправного членства України в Європейському Союзі та в Організації Північноатлантичного договору [Електронний ресурс] / Режим доступу:https://zakon.rada.gov.ua/laws/show/2680-19)

2. Про затвердження стандарту вищої освіти за спеціальністю 253 «Військове управління (за видами збройних сил) для першого бакалаврського рівня. / Наказ Міністерства освіти і науки України № 1168 від 29.10.2018. [Електронний ресурс]/ Режим доступу: https://mon.gov.ua/storage/app/media/vishcha-osvita/zatverdzeni\%20 standarty/12/21/253-viyskove-upravlinnya-za-vidami-zbroynikh-silbakalavr.pdf

3. Про затвердження стандарту вищої освіти за спеціальністю 254 «Забезпечення військ (сил)» для першого (бакалаврського) рівня. / Наказ Міністерства освіти і науки України № 1385 від 12.12.2018. [Електронний ресурс]/ Режим доступу: https://mon.gov.ua/storage/ app/media/vishcha-osvita/zatverdzeni\%20standarty/12/21/254zabezpechennya-viysk-sil-bakalavr.pdf

4. Про затвердження стандарту вищої освіти за спеціальністю 255 «Озброєння та військова техніка» для першого (бакалаврського) рівня. / Наказ Міністерства освіти і науки України № 1341 від 05.12.2018. [Електронний ресурс] / Режим доступу: https://mon.gov.ua/storage/ app/media/vishcha-osvita/zatverdzeni\%20standarty/12/21/255-ozbroennyata-viyskova-tekhnika-bakalavr.pdf 